DOl:10.52562/kapita.vli1.300
KAPITA:
Jublishing
Jurnal Agribisnis \& Pembangunan Pertanian
htt/journal.moripublishing.com/index.php/kapita

\title{
Sensitivitas Usaha Peternakan Sapi Perah pada Peternakan Bestcow Farm Jember
}

\author{
Huda Ahmad Hudori ${ }^{\text {* }}$, Hari Rujito², Muksin³ \\ 'Program Studi Agribisnis, Politeknik Negeri Jember; \\ 2.3 Program Studi Magister Agribisnis, Politeknik Negeri Jember. \\ "Corresponding author: huda.ahmadhudori@yahoo.com
}

\begin{abstract}
Abstrak: Penelitian ini bertujuan untuk: a) mengkaji tingkat kepekaan (sensitivitas) usaha peternakan sapi perah Bestcow Jember apabila terjadi kenaikan total biaya produksi dan penurunan harga susu segar, dan b) mengkaji tingkat kepekaan (sensitivitas) usaha peternakan sapi perah Bestcow Jember apabila terjadi penurunan harga output (susu segar dan pedet). Pemilihan lokasi penelitian dilakukan secara sengaja (Purposive) dengan pertimbangan karena peternakan Bestcow Farm memiliki populasi ternak sapi perah yang cukup banyak dibandingkan dengan tempat lainnya di Jember. Waktu Penelitian ini dimulai dari pengumpulan data yang dilaksanakan mulai bulan Februari sampai Mei 2017. Metode analisis yang digunakan adalah Linier Programing untuk menyusun ransum, analisis biaya, pendapatan, keuntungan, efisiensi usaha dan sensitivitas. Hasil penelitian menunjukkan bahwa: a) Biaya pakan yang dikeluarkan adalah Rp.1.792.500/ hari, dengan penggunaan ransum alternatif dapat menghemat biaya pakan sebesar Rp.265.302/ hari. b) keuntungan yang diperoleh dalam satu tahun sebesar Rp. 88.084.392,86. c) efisiensi usaha didapatkan R/C Ratio sebesar 1,09 dan d) sensitivitas usaha sangat rentan terhadap kenaikan biaya pakan dan tidak layak lagi untuk dilanjutkan pada kenaikan biaya pakan sebesar 15\%.
\end{abstract}

Kata Kunci: Peternakan Sapi Perah, Efisiensi Usaha dan Sensitivitas.

\begin{abstract}
This study aims to: a) examine the sensitivity level of the Bestcow Jember dairy farming business if there is an increase in total production costs and a decrease in the price of fresh milk, and b) examine the sensitivity level of the Bestcow Jember dairy farming business if there is a decrease in prices. output (fresh milk and calf). The research location was chosen purposively with the consideration that Bestcow Farm has a large population of dairy cattle compared to other places in Jember. The time of this research started from data collection which was carried out from February to May 2017. The analytical method used was Linear Programming to prepare rations, analyze costs, income, profits, business efficiency and sensitivity. The results showed that: a) The cost of feed spent was $R p .1,792,500 /$ day, with the use of alternative rations, the cost of feed was Rp. 265,302/day. b) the profit earned in one year is Rp. 88,084,392.86. c) business efficiency obtained an R/C Ratio of 1.09 and d) business sensitivity is very vulnerable to increases in feed costs and is no longer feasible to continue with a $15 \%$ increase in feed costs.
\end{abstract}

Keywords: Dairy Farming, Business Efficiency and Sensitivity.

\section{PENDAHULUAN}

Usaha peternakan sapi perah adalah usaha dengan prospek pengembangan yang cerah karena dilihat dari laju permintaan susu yang terus mengalami peningkatan, adanya dukungan perbaikan manajemen, teknologi, infrastuktur, dan kebijakan dari peme-rintah. Pengembangan usaha peternakan sapi perah merupakan salah satu alternatif dalam rangka pemenuhan gizi masyarakat terutama yang berasal dari protein hewani terutama susu. Prediksi perkembangan industri pengolahan susu di Indonesia bahwa konsumsi susu masyarakat pada tahun 2020 adalah sebesar 6 milyar liter setara susu segar atau 16,5 juta liter per hari (Cahyawati, 2015). 
Populasi ternak sapi perah di Indonesia tahun 2015 tercatat 519.000 ekor (Direktorat Jenderal Peternakan dan Kesehatan Hewan, 2018). Sapi perah di Indonesia 97\% dari populasi terkonsentrasi di Pulau Jawa dengan rataan produksi susu per ekor sekitar 11 sampai 12 liter/hari (Cahyawati et al., 2014). Produksi tersebut masih jauh di bawah produksi susu yang seharusnya. Salah satu usaha yang dapat dilakukan adalah dengan pengembangan sapi perah untuk menunjang peningkatan produksi susu dalam negeri. Selama ini, pemerintah Indonesia mengatasi kekurangan pasokan susu dalam negeri dengan melakukan impor susu dari Australia dan New Zealand. Saat ini susu segar dalam negeri (SSDN) baru mencapai 30\% kebutuhan nasional, sedangkan 70\% dipenuhi melalui impor (Cahyawati, 2015).

Peningkatan produksi susu sapi perah perlu dilakukan karena peluang pasar di dalam negeri sangat terbuka lebar mengingat sekitar 70\% kebutuhan susu nasional masih diperoleh dari impor dengan volume impor pada tahun 2015 sebesar 286.412 ton. Saat ini populasi sapi perah di Indonesia masih terpusat di pulau Jawa dengan sebaran Provinsi Jawa Timur 45,6\%, Jawa Tengah 27,7\%, Jawa Barat 23,5\%, dan 3,2\% sisanya Provinsi lain (Direktorat Jenderal Peternakan, 2015). Indonesia memiliki potensi yang sangat besar di sektor agribisnis. Kekayaan sumberdaya agribisnis berperan sebagai pendukung usaha peternakan sapi perah, sehingga istilah Indonesia sebagai kolam susu akan terwujud serta dapat menjadi lokomotif bagi stimulasi pembangunan nasional.

Perusahaan sapi perah mempunyai tujuan untuk mendapatkan keuntungan yang sebesarbesarnya. Adapun untuk memperoleh keuntungan yang besar suatu usaha sapi perah perlu melakukan efisiensi di dalam menggunakan biaya produksi guna mendapatkan output susu segar yang banyak. Salah satu cara yang dapat dilakukan untuk menekan pengeluaran biaya operasional pada usaha peternakan sapi perah adalah dengan menekan biaya pakan lebih murah sehingga akan diperoleh keuntungan yang optimal.

Bestcow Farm merupakan salah satu perusahaan sapi perah yang ada di Jember. Perusahaan peternakan memiliki permasalahan utama yaitu rentan terhadap perubahan kenaikan biaya produksi dan penurunan harga jual output. Tidak terkecuali juga pada usaha peternakan sapi perah. Oleh karena itu, penelitian ini dilakukan untuk mengetahui bagaimana tingkat sensitivitas usaha peternakan sapi perah di Bestcow Farm Jember apabila terjadi perubahan kenaikan biaya produksi dan penuruhan harga output.

\section{METODE PENELITIAN \\ Lokasi dan Waktu Penelitian}

Penelitian ini dilakukan di peternakan sapi perah Bestcow Farm Kecamatan Ajung Kabupaten Jember. Pemilihan lokasi penelitian dilakukan secara sengaja (Purposive) dengan pertimbangan karena peternakan Bestcow Farm memiliki populasi ternak sapi perah yang cukup banyak dibandingkan dengan tempat lainnya di Jember. Waktu Penelitian ini dimulai dari pengumpulan data yang dilaksanakan mulai bulan Februari sampai Mei 2017.

\section{Metode Pengumpulan Data dan Informasi}

Penelitian ini dilakukan dengan menggunakan data primer dan data sekunder. Data primer adalah data yang diperoleh langsung dari wawancara dengan karyawan perusahaan. Data sekunder adalah data yang diperoleh berdasarkan pencatatan secara langsung dari instansi yang ada hubungannya dengan penelitian ini, yaitu Peternakan sapi perah Bestcow Farm dan Dinas Peternakan, Perikanan dan Kelautan Jember. Data yang dikumpulkan dari tempat penelitian meliputi biaya-biaya yang dikeluarkan selama kegiatan proyek berlangsung dan penjualan output yang dihasilkan berupa susu segar dan pedet.

\section{Metode Analisis Data}

Analisis data yang digunakan dalam penelitian ini adalah metode analisis deskriptif. Metode ini digunakan untuk mendeskripsikan fenomena-fenomena penggunaan faktor produksi dan keuntungan dari usaha peternakan sapi perah Bestcow Farm Jember. Penelitian ini berupa evaluasi 
proyek (tahun 2016-2017) dan perencanaan/ estimasi kedepan hingga tahun 2020, jadi data yang digunakan dalam analisis ini adalah 5 tahun sesuai dengan umur ekonomis sapi perah.

\section{Analisis Pendapatan dan Keuntungan}

Analisis ini digunakan untuk mengetahui pendapatan/ keuntungan yang diperoleh usaha Peternakan sapi perah, rumus yang digunakan menurut Soekartawi (1993) dalam Sangadji (2018) adalah:

$\pi=\mathrm{TR}-\mathrm{TC}$

Keterangan :

$\pi \quad=$ Keuntungan

TR $=$ Total penerimaan

TC $=$ Total Biaya

Total penerimaan pada usaha peternakan sapi perah diperoleh dari hasil penjualan susu segar, pedet dan induk yang sudah afkir. Sedangkan total biaya merupakan gabungan dari biaya penusutan dan biaya operasional.

\section{Analisis Efisiensi Biaya}

Permasalahan tentang efisiensi penggunaan biaya produksi usaha peternakan sapi perah dikaji dengan menggunakan R/C Ratio. Menurut Marsaoly dkk (2020) secara matematis analisis R/C Ratio dapat diformulasikan sebagai berikut:

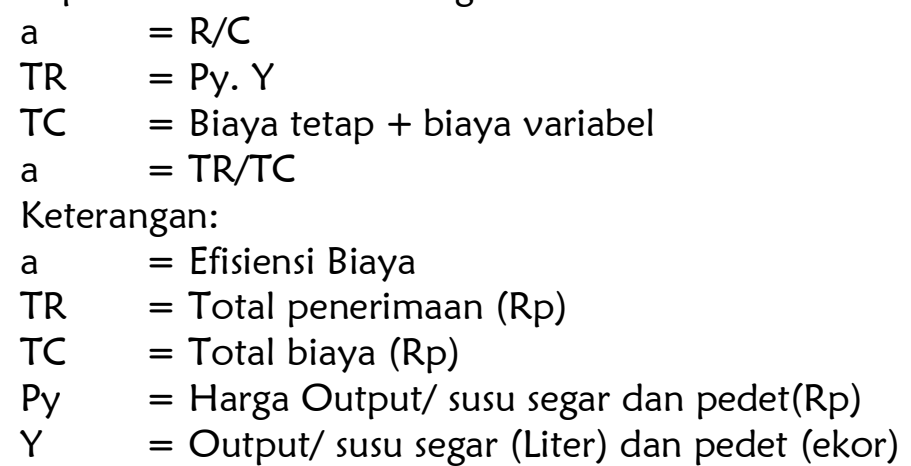

Analisis R/C Ratio dipergunakan untuk mengetahui besarnya penerimaan yang diterima peternak dari setiap rupiah yang dikeluarkan pada suatu usaha ternaknya.

\section{Analisis Sensitivitas}

Analisis ini dilakukan untuk mengetahui kepekaan usaha peternakan sapi perah terhadap perubahan kenaikan biaya produksi terutama pakan atau penuruan harga output (susu segar dan pedet). Sehingga dapat diketahui tentang kerentanan usaha tersebut dan bisa digunakan sebagai pertimbangan pengambilan keputusan. Pada penelitian ini analisis sensitivitas dilakukan pada :

1. Kenaikan harga pakan sebesar 5\%, $10 \%$ dan 15\% dengan harga output (susu segar dan pedet) tetap;

2. Penurunan harga output (susu segar dan pedet) sebesar $5 \%, 10 \%$ dan $15 \%$ dengan harga pakan tetap tetap;

3. Kenaikan harga pakan sebesar $5 \%, 10 \%$ dan $15 \%$ dengan penuruan harga output (susu segar dan pedet) sebesar $5 \%, 10 \%$ dan $15 \%$.

\section{HASIL DAN PEMBAHASAN}

\section{Penerimaan Usaha Peternakan Sapi Perah}

Analisis penerimaan dari usaha peternakan sapi perah diperoleh dari hasil penjualan susu segar, pedet dan induk afkir. Penerimaan yang diperoleh dari usaha peternakan sapi perah pada Bestcow Farm secara umum diperoleh dari tiga penjualan output utama yaitu penjualan susu segar dan pedet, sedangkan penerimaan tambahan diperoleh dari penjualan induk yang afkir. Adapun penerimaan 
yang diperoleh dari penjualan susu segar sebanyak 143.009 liter dan dijual ke Koperasi susu dengan harga Rp 5.250/ liter. Total penerimaan dari susu segar sebesar Rp. 750.797 .250 atau sebesar $71,88 \%$. Selain susu segar penjualan pedet sebesar Rp. $136,500.00$ atau sebesar $16,15 \%$ dan penjualan induk yang sudah afkir sebesar Rp. 125.000 .00 atau sebesar $11,97 \%$. Penerimaaan usaha sapi perah dapat dilihat pada Tabel 2.

Tabel 2. Penerimaan Usaha Peternakan Sapi Perah Bestcow Farm

\begin{tabular}{cccccc}
\hline Penerimaan & Satuan & Jumlah & $\begin{array}{c}\text { Harga Satuan } \\
(\mathrm{Rp})\end{array}$ & Nilai (Rp) & $\begin{array}{c}\text { Persentase } \\
(\%)\end{array}$ \\
\hline Susu & Liter & 143009 & 5.250 & 750.797 .250 & 71,88 \\
Pedet & Ekor & 42 & 3.7500 .000 & 168.750 .000 & 16,15 \\
Induk Afkir & Ekor & 10 & 12.500 .000 & 125.000 .000 & 11,97 \\
\hline \multicolumn{7}{c}{ Total Penerimaan } & & 1.044 .547 .250 & 100 \\
\hline
\end{tabular}

\section{Biaya Usaha Peternakan Sapi Perah}

Biaya usaha peternakan sapi perah di Bestcow Farm Jember terdiri dari dua bagian yaitu biaya tetap atau fixcost dan biaya variabel atau variablecost. Biaya tetap merupakan biaya yang dikeluarkan untuk membeli keperluan kandang dan semua peralatan atau biaya investasi yang digunakan untuk budidaya seperti: bangunan kandang, kantor dan perlatan kandang lainnya. Sedangkan untuk biaya variabel adalah biaya yang dikeluarkan untuk kegiatan operasional usaha peternakan seperti: pakan (hijauan dan konsentrat), tenaga kerja, air, listrik, IB dan pajak.

Total biaya usaha peternakan sapi perah Bestcow Farm selama tahun 2016 sebesar Rp. 956.462.857 yang terdiri dari biaya tetap diperhitungkan penyusutan tiap tahun sebesar Rp. 170.402.857. sedangkan biaya variabel atau operasional adalah sebesar Rp. 786.060 .000 yang terdiri dari: pakan, Inseminasi Buatan (IB), Vitamin dan obat, tenaga kerja, listrik, air dan BBM.

\section{Pendapatan dan Efisiensi Usaha Peternakan Sapi Perah}

Pendapatan usaha peternakan sapi perah di Bestcow Farm dihitung dengan melihat selisih antara penerimaan dengan pengeluaran usaha sapi perah. Pendapatan usaha ini dihitung dari pendapatan atas biaya variabel dan pendapatan atas biaya total. Sedangkan efisiensi usaha peternakan sapi perah dihitung menggunakan perbandingan antara nilai output terhadap nilai inputnya sehingga diketahui kelayakan usaha ternak yang diusahakan di Bestcow Farm Jember.

Usaha peternakan sapi perah Bestcow Farm Jember pendapatan atau keuntungan yang diterima dalam satu tahun sebanyak Rp. 88.084.392,86 sedangkan untuk pendapatan perhari sebanyak Rp.244.678,87. Adapun R/C Ratio yang diperoleh atas biaya variabel sebesar 1,32 dan R/C Ratio atas total biaya sebesar 1,09. Dari hasil R/C Ratio tersebut dapat diartikan bahwa usaha peternakan sapi perah setiap pengeluaran sebesar Rp. 1 akan diperoleh pendapatan sebesar Rp. 1,09. Artinya usaha peternakan tersebut layak untuk diteruskan asalkan tidak terjadi perubahan kenaikan biaya dan penurunan harga output.

\section{Sensitivitas}

Kelayakan suatu usaha dapat berubah karena disebabkan adanya suatu perubahan pada faktor-faktor biaya dan penerimaan, sebagai akibatnya dapat saja suatu proyek yang semula layak untuk diusahakan menjadi tidak layak lagi untuk diusahakan. Pada usaha peternakan sapi perah, perubahan kenaikan harga pakan dan penurunan harga susu segar sangat besar pengaruhnya karena merupakan komponen utama yang memberikan terbesar pada arus output input usaha peternakan sapi perah. Perubahan tersebut merupakan suatu kerentanan dalam suatu usaha peternakan sapi perah.

Analisis sensitivitas dilakukan untuk melihat kembali suatu perhitungan kelayakan usaha, terhadap suatu pengaruh yang mungkin akan terjadi akibat perubahan keadaan (perubahan total biaya produksi maupun harga output/ susu segar dan pedet) terhadap kelangsungan usaha 
peternakan sapi perah Bestcow Farm Jember. Analisis sensitivitas bertujuan untuk memperhitungkan sampai seberapa jauh perusahaan mampu menghadapi resiko-resiko ketidak pastian dimasa mendatang. Adanya analisis ini dapat membantu mengarahkan pimpinan perusahaan terhadap perubahan yang terjadi baik perkiraan biaya yang dikeluarkan maupun benefit serta pimpinan dapat mengambil tindakan untuk mengatasi hal tersebut.

\section{Tingkat Kepekaan (Sensitivitas) Perubahan Kenaikan Harga Pakan dan Penurunan Harga Output (Susu Segar dan Pedet) terhadap Keuntungan}

Analisis sensitivitas atau kepekaan akan menambah tingkat kepercayaan atas suatu proyek usaha yang dihasilkan. Penelitian ini, analisis kepekaan dilakukan dengan simulasi sampai terjadi perubahan yang dapat mempengaruhi keputusan investasi usaha peternakan sapi perah pada Bestcow Farm Jember. Analisis sensitivitas ini dilakukan dengan simulasi terhadap kenaikan biaya pakan dan penurunan harga output (susu segar dan pedet). Pada usaha peternakan sapi perah biaya pakan sering mengalami fluktuasi yang tidak pasti sehingga perlu dilakukan antisipasi. Hasil analisis sensitivitas dengan kenaikan biaya pakan dan penurunan harga output ditunjukkan pada Tabel 3.

Tabel 3. Sensitivitas Keuntungan Usaha Peternakan Sapi Perah BestcowFarm dengan Harga Pakan dan Susu Segar berubah

\begin{tabular}{lcccc}
\hline Harga & \multicolumn{4}{c}{ Harga Otput } \\
\cline { 2 - 5 } Pakan & \multicolumn{1}{c}{ Tetap } & \multicolumn{1}{c}{ Turun 5\% } & \multicolumn{1}{c}{ Turun 10\% } & Turun 15\% \\
\hline tetap & 88.084 .393 & $61.970 .711,61$ & $35.857 .030,36$ & $9.743 .349,11$ \\
Naik 5\% & 55.819 .393 & $29.705 .711,61$ & $3.592 .030,36$ & $(22.521 .650,89)$ \\
Naik 10\% & $23.554 .392,86$ & $(2.559 .288,39)$ & $(28.672 .969,64)$ & $(54.786 .650,89)$ \\
Naik 15\% & $(8.710 .607,14)$ & $(34.824 .288,39)$ & $(60.937 .969,64)$ & $(87.051 .650,89)$ \\
\hline
\end{tabular}

Usaha peternakan sapi perah Bestcow Farm tetap masih layak untuk diusahakan apabila dalam kondisi seperti berikut: biaya pakan tetap dan harga output tetap atau terjadi penurunan sampai $15 \%$, biaya pakan naik $5 \%$ dan harga output tetap atau turun sampai $10 \%$, biaya pakan naik $10 \%$ dan harga output tetap. Selanjutnya usaha peternakan sapi perah akan menjadi tidak layak karena akan mengalami kerugian apabila terjadi kenaikan biaya pakan $5 \%$ dan pada waktu yang sama harga output turun $15 \%$, biaya pakan naik $10 \%$ dan harga output turun $5 \%$ atau pada biaya pakan naik $15 \%$ walaupun harga output tetap atau tidak ada penurunan.

Analisis sensitivitas ini menunjukkan bahwa usaha peternakan sapi perah pada Bestcow Farm Jember lebih rentan terhadap kenaikan biaya pakan dibandingkan dengan terjadinya penurunan harga output.

\section{Tingkat Kepekaan (Sensitivitas) Perubahan Kenaikan Harga Pakan dan Penurunan Harga Output (Susu Segar dan Pedet) terhadap Efisiensi Usaha (R/C Ratio)}

Biaya pakan dan harga output dalam perhitungan termasuk dalam item pengeluaran dan penerimaan. Jika biaya pakan naik dan harga output menurun akan berpengaruh terhadap efisiensi usaha peternakan sapi perah. Sensitivitas juga dilakukan untuk mengukur tingkat efisiensi suatu usaha peternakan sapi perah apabila terjadi kenaikan biaya pakan dan penurunan harga output. Hasil analisis sensitivitas terhadap efisiensi R/C Ratio pada peternakan sapi perah Bestcow Farm Jember saat terjadi kenaikan biaya pakan disajikan pada Tabel 4.

Tabel 4. Sensitivitas Efisiensi R/C Ratio Usaha Peternakan Sapi Perah Bestcow Farm dengan

Kenaikan Harga Pakan

\begin{tabular}{|c|c|c|c|c|c|}
\hline \multirow[t]{2}{*}{ No } & \multirow{2}{*}{ Kriteria } & \multicolumn{4}{|c|}{ Kenaikan Harga Pakan } \\
\hline & & Tetap & Naik $5 \%$ & Naik $10 \%$ & Naik $15 \%$ \\
\hline 1 & R/C Ratio & 1,092 & 1,056 & 1,023 & 0,99 \\
\hline
\end{tabular}


Kenaikan biaya pakan berpengaruh terhadap R/C Ratio yang dihasilkan, dimana usaha masih layak dan efisein untuk dijalankan dengan kenaikan biaya pakan naik 5 dan $10 \%$ dengan harga output tetap. Kenaikan biaya pakan $15 \%$ menyebabkab usaha peternakan menjadi tidak layak dan efisien untuk dijalankan karena akan kerugian yang akan diperoleh.

Analisis sensitivitas pada hasil R/C Ratio yang dihasilkan juga dilakukan pada penurunan harga output. Analisis ini dilakukan untuk mengetahui efiseinsi usaha perternakan sapi perah terhadap penuruan harga output. Hasil analisis sensitivitas terhadap efisiensi R/C Ratio pada peternakan sapi perah Bestcow Farm Jember saat terjadi penurunan harga output disajikan pada Tabel 5.

Tabel 5. Sensitivitas Efisiensi R/C Ratio Usaha Peternakan Sapi Perah Bestcow Farm dengan Penurunan Harga Output

\begin{tabular}{lccccc}
\hline \multirow{2}{*}{ No } & \multirow{2}{*}{ Kriteria } & \multicolumn{3}{c}{ Penurunan Harga Output } \\
\cline { 3 - 6 } 1 & Retap & Turun 5\% & Turun $10 \%$ & Turun 15\% \\
& R/C Ratio & 1,092 & 1,065 & 1,037 & 1,010 \\
\hline
\end{tabular}

Usaha peternakan sapi perah pada Bestcow Farm masih layak untuk dilanjutkan pada kondisi apabila terjadi penurunan harga output (susu segar dan pedet) sebesar $5 \%, 10 \%$ dan $15 \%$ dengan asumsi biaya pakan tetap. Upaya-upaya yang dapat dilakukan untuk menanggulangi masalahmasalah yang akan dihadapi dimasa mendatang jika terjadi kenaikan biaya produksi dan penurunan harga output adalah dengan jalan melakukan tindakan seperti: meningkatkan produksi susu yang dihasilkan, menggunakan formulasi ransum alternatif yang lebih murah yang dapat menekan biaya pakan yang dikeluarkan. Dimana dari hasil analisis sensitivitas bahwa kenaikan biaya pakan lebih rentan dibandingkan dengan penurunan harga output terhadap efisiensi usaha peternakan sapi perah.

\section{KESIMPULAN}

Berdasarkan hasil dan pembahasan terhadap hasil penelitian maka dapat ditarik suatu kesimpulan sebagai berikut: 1.) Penerimaan usaha peternakan sapi perah Bestcow Farm Jember diperoleh dari tiga penjualan output yaitu berupa: susu segar $71,88 \%$, pedet $16,15 \%$ dan induk yang afkir $11,97 \%$; 2.) Penggunaan biaya pakan pada usaha peternakan sapi perah sebesar $67,48 \%$ dari total biaya, dengan menggunakan ransum alternatif biaya pakan bisa turun menjadi 64,05\%; 3.) Analisis sensitivitas usaha peternakan Bestcow Farm dengan menggunakan formulasi pakan alternatif mampu mengantisipasi kerentanan usaha peternakan sapi perah dari kerugian terhadap kenaikan biaya pakan $5-15 \%$ dan penurunan harga output $5-15 \%$; 4.) Usaha peternakan sapi perah Bestcow Farm Jember lebih rentan pada kenaikan biaya pakan dibandingkan dengan penurunan harga output (susu segar dan pedet).

\section{DAFTAR PUSTAKA}

Aisyah, Siti. (2012). Analisis Efisiensi Penggunaan Faktor-faktor Produksi pada Usaha Ternak Sapi Perah Rakyat di Kecamatan Getasan Kabupaten Semarang. JURNAL: Economics Development Anayisis Journal 1 (1)

Cahyawati, Anggraeni E. (2015). Analisis Efisiensi Teknis, Keterampilan Teknis Beternak dan Pendapatan pada Usaha Peternakan Sapi Perah Rakyat di Kecamatan Lembang. TESIS. Sekolah Pascasarjana Institut Pertanian Bogor: Bogor

Direktorat Jenderal Peternakan. (2015). Buku Statistik Peternakan dan Kesehatan Hewan. Jakarta. Kementerian Pertanian

Elida, Septina. (2016). Potensi dan Strategi Pengembangan Usaha Ternak Sapi Perah di Kecamatan Pangkalan Kerinci Kabupaten Pelalawan. JURNAL. Gontor AGROTECH Science Journal Vol. 2 No. 2, Juni 2016

Firman, Achmad. (2010). Agribisnis Sapi Perah dari Hulu sampai Hilir. Bandung: Widya Padjadjaran Hidayat, Syukro dan Mukhlash, Iman. (2015). Rancang Bangun dan Implementasi Sistem Pendukung Keputusan Berbasis Web untuk Menentukan Formulasi Ransum Pakan Ternak. Jurusan 
Matematika, Fakultas MIPA, Institut Teknologi Sepuluh Nopember (ITS). JURNAL Sains dan Seni ITS Vol. 4, No.2

Mubyarto. (1995). Pengantar Ekonomi Pertanian. Yogyakarta: LP3ES

Marsaoly, H. A., Sangadji, S. S., \& Sumartono, E. (2020). Analisis Profitabilitas Usaha Tani Bawang Merah Pada Unit Transmigrasi (Trans Koli). AGRITEPA: Jurnal IImu dan Teknologi Pertanian, $7(2), 142-151$.

NRC. (2001). Nutrient Requirement of Dairy Cattle. 8th Edition. National Academic of Science, Washington D. C.

Noor, H.F. (2007). Ekonomi Manajerial. Jakarta: PT Raja Grafindo Persada.

Nurmalina R, Tintin S dan Karyadi A. (2010). Studi Kelayakan Bisnis. Bogor: Departemen Agribisnis Fakultas Ekonomi dan Manajemen.

Rahayu, ET. (2013). Analisis Pendapatan Usaha Ternak Sapi Perah di Kecamatan Cepogo Kabupaten Boyolali. JURNAL: Sains Peternakan Vol. 11 (2)

Saragi, Mega Pratiwi. (2014). Potensi dan Kualitas Limbah Pertanian sebagai Pakan di Kabupaten Bandung dan Bogor untuk Pengembangan Budidaya Ternak Sapi Perah. TESIS. Sekolah Pascasarjana Institut Pertanian Bogor: Bogor

Sangadji, S. S. (2018). Profitability Analysis of Terubuk Farming (Saccharum Edule Hasskarl) in Subdistrict Tosa District of East Tidore of Tidore Island. Jurnal Akrab Juara, 3(2), 168-174.

Santosa, S. Imam. (2013). Analisis Potensi Pengembangan Usaha Peternakan Sapi Perah dengan Menggunakan Paradigma Agribisnis di Kecamatan Musuk Kabupaten Boyolali. JURNAL. Buletin Peternakan. Vol. 37 (2): 125-135, Juni 2013

Soekartawi. (1993). Agribisnis Teori dan Aplikasinya. Jakarta: PT Raja Grifindo Persada . (1995). Dasar Penyusunan Evaluasi Proyek. Jakarta: Pustaka Sinar Harapan.

Sudono, A., Fina dan Budi. (2003). Beternak Sapi Perah Secara Intensif. Penerbit Agromedia Pustaka. Depok.

Warsito, Sunaryo H. (2009). Analisis Finansial, Resiko Dan Sensitivitas Usaha Peternakan Ayam Petelur (Survei pada Kelompok Peternak Gunungrejo Makmur Kabupaten Lamongan). TESIS. Program Studi Ilmu Ternak Pascasarjana Universitas Brawijaya: Malang. 